\title{
Identification and Elimination of Mechanisms Leading to UV Damage of DKDP
}

A. Burnham, M. Runkel, L. Chase, S. Demos, M. Staggs, W. Siekhaus

\section{March 6, 2001}




\section{DISCLAIMER}

This document was prepared as an account of work sponsored by an agency of the United States Government. Neither the United States Government nor the University of California nor any of their employees, makes any warranty, express or implied, or assumes any legal liability or responsibility for the accuracy, completeness, or usefulness of any information, apparatus, product, or process disclosed, or represents that its use would not infringe privately owned rights. Reference herein to any specific commercial product, process, or service by trade name, trademark, manufacturer, or otherwise, does not necessarily constitute or imply its endorsement, recommendation, or favoring by the United States Government or the University of California. The views and opinions of authors expressed herein do not necessarily state or reflect those of the United States Government or the University of California, and shall not be used for advertising or product endorsement purposes.

This report has been reproduced directly from the best available copy.

Available electronically at http://www.doc.gov/bridge

Available for a processing fee to U.S. Department of Energy

And its contractors in paper from

U.S. Department of Energy

Office of Scientific and Technical Information

P.O. Box 62

Oak Ridge, TN 37831-0062

Telephone: (865) 576-8401

Facsimile: (865) 576-5728

E-mail: reports@adonis.osti.gov

Available for the sale to the public from

U.S. Department of Commerce

National Technical Information Service

5285 Port Royal Road

Springfield, VA 22161

Telephone: (800) 553-6847

Facsimile: (703) 605-6900

E-mail: orders@ntis.fedworld.gov

Online ordering: http://www.ntis.gov/ordering.htm

OR

Lawrence Livermore National Laboratory

Technical Information Department's Digital Library

http://www.llnl.gov/tid/Library.html 


\title{
Identification and Elimination of Mechanisms Leading to UV Damage of DKDP*
}

\author{
Alan Burnham, Mike Runkel, Lloyd Chase, Stavros Demos, Mike Staggs, \\ Wigbert Siekhaus
}

This LDRD project addressed both bulk and surface damage induced by UV-laser exposure. The primary objectives were (1) to complete our understanding of the factors leading to bulk damage, including growth conditions and orientational direction, and (2) to identify mechanisms of surface damage initiation and growth leading to mitigation methods.

Due to the more advanced state of knowledge in bulk damage, a greater portion of that work was completed during the one-year term of this project. Three papers were presented at the 32nd Boulder Damage Symposium on Laser-Induced Damage in Optical Materials, and the three resulting manuscripts submitted to the Proceeding are attached. An important result from this work is that it established a dependence of obscuration from bulk damage on fluence and pulse length, which is shown in Figure 1.

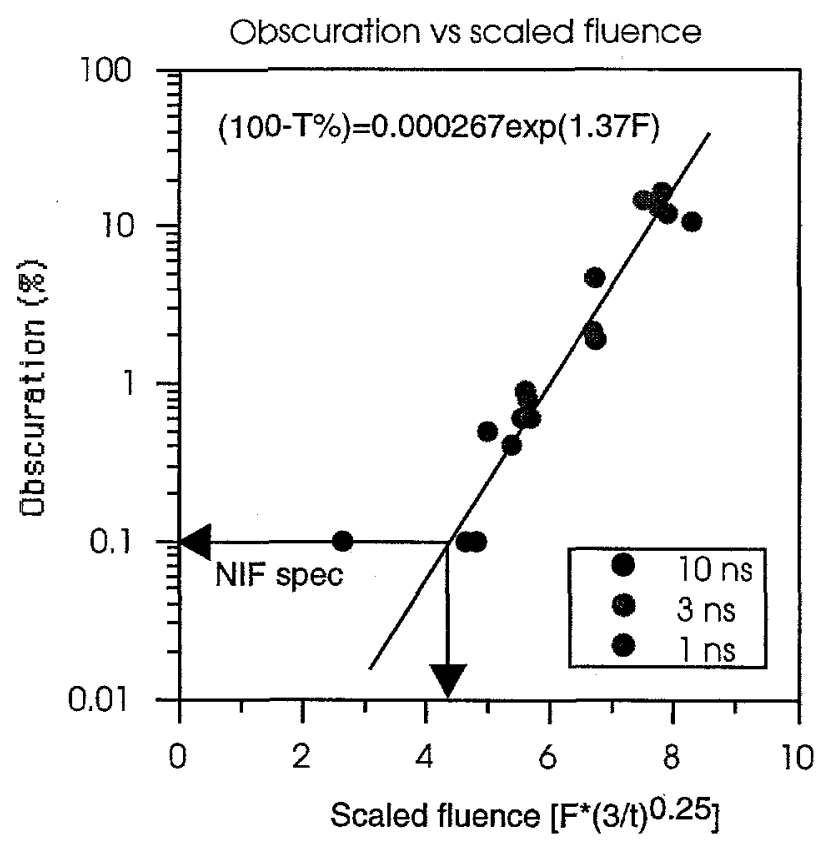

Figure 1 . Obscuration by scattering from laser-induced bulk damage as a function of the single-pulse exposure fluence scaled by $\mathrm{t}^{0.25}$.

\footnotetext{
* Work supported under the auspices of the U.S. Department of Energy by the University of California Lawrence Livermore National Laboratory under contract No. W-7405-ENG-48.
} 
Two techniques were explored to identify the precursors of bulk damage. One was laser-induced breakdown of the DKDP growth solution, using either acoustic or emission detection. The other was analysis of particulate captured from dissolved crystals passed through 40-nm track-etched filter. The first method had mixed results and did not clearly demonstrate a signal above background that could be definitively related to the growth solution. The second method gave more promising results, with control experiments clearly showing the ability to collect and analyze gold nanoparticles, as shown in Figure 2. The technique was transferred to the NIF project at the end of the LDRD project.
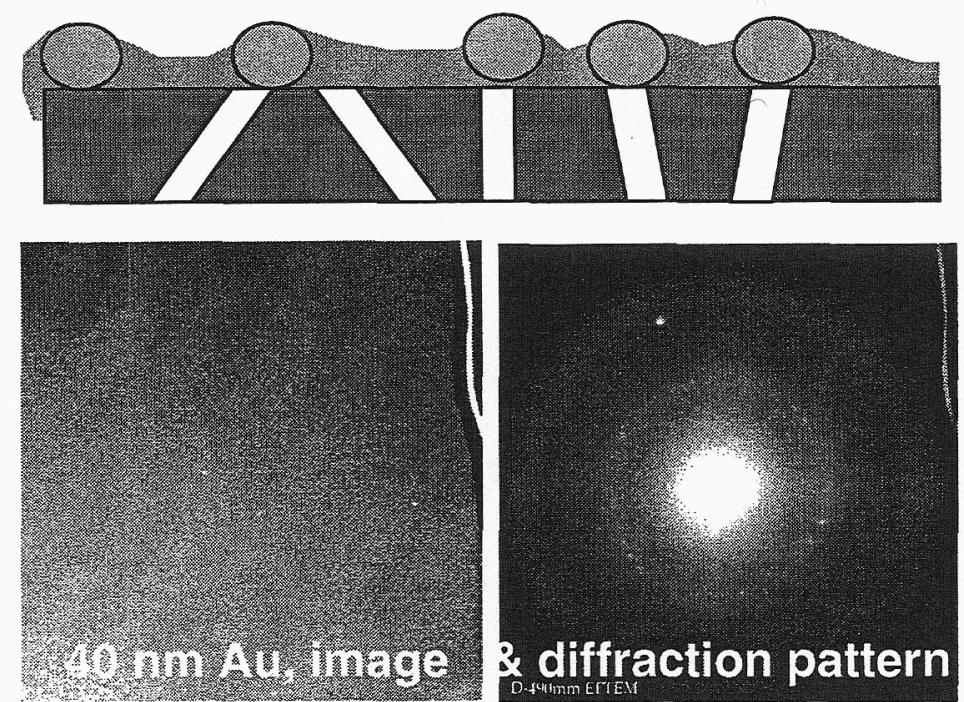

Figure 2. Figure showing schematically the capture of nanoparticles on a track-etched filter, a TEM image showing gold particles, and a diffraction pattern confirming the $\mathrm{Au}$ composition.

For surface damage, we explored the correlation between microscopic fluorescent bodies in the crystal surface and the subsequent occurrence of laser-induced surface damage. On a crystal with a relatively poor quality surface, four of four imbedded fluorescent bodies damaged at the high end of NIF fluences. One of these sites is shown in the Figure 3 below. In contrast, surface particles blew off without causing crater damage. High quality crystals have only a couple surface damage events per $100 \mathrm{~cm}^{2}$, so on the basis of these results, we started setting up a raster scanning system that couples fluorescence and scattering imaging with an in-situ damage measurement system. The system was partially constructed at the end of the LDRD project.

During the year, an interesting new phenomenon was discovered and a likely mechanism proposed. Small surface cracks with an orientation along the extraordinary axis of tripler cut DKDP samples were observed. The cracks formed both spontaneously and when the pieces were indented with a nanoindentor in preparation for surface damage growth experiments. The cause appears to be the formation of a surface layer in tension due to exchange of deuterium in the crystal with hydrogen from ambient moisture in the air. The lattice parameters of the resulting DKP layer are $0.2 \%$ lower than the underlying 
DKDP layer. The surface exchange from a few to tens of microns was measured by both Raman spectroscopy and Secondary Ion Mass Spectrometry.

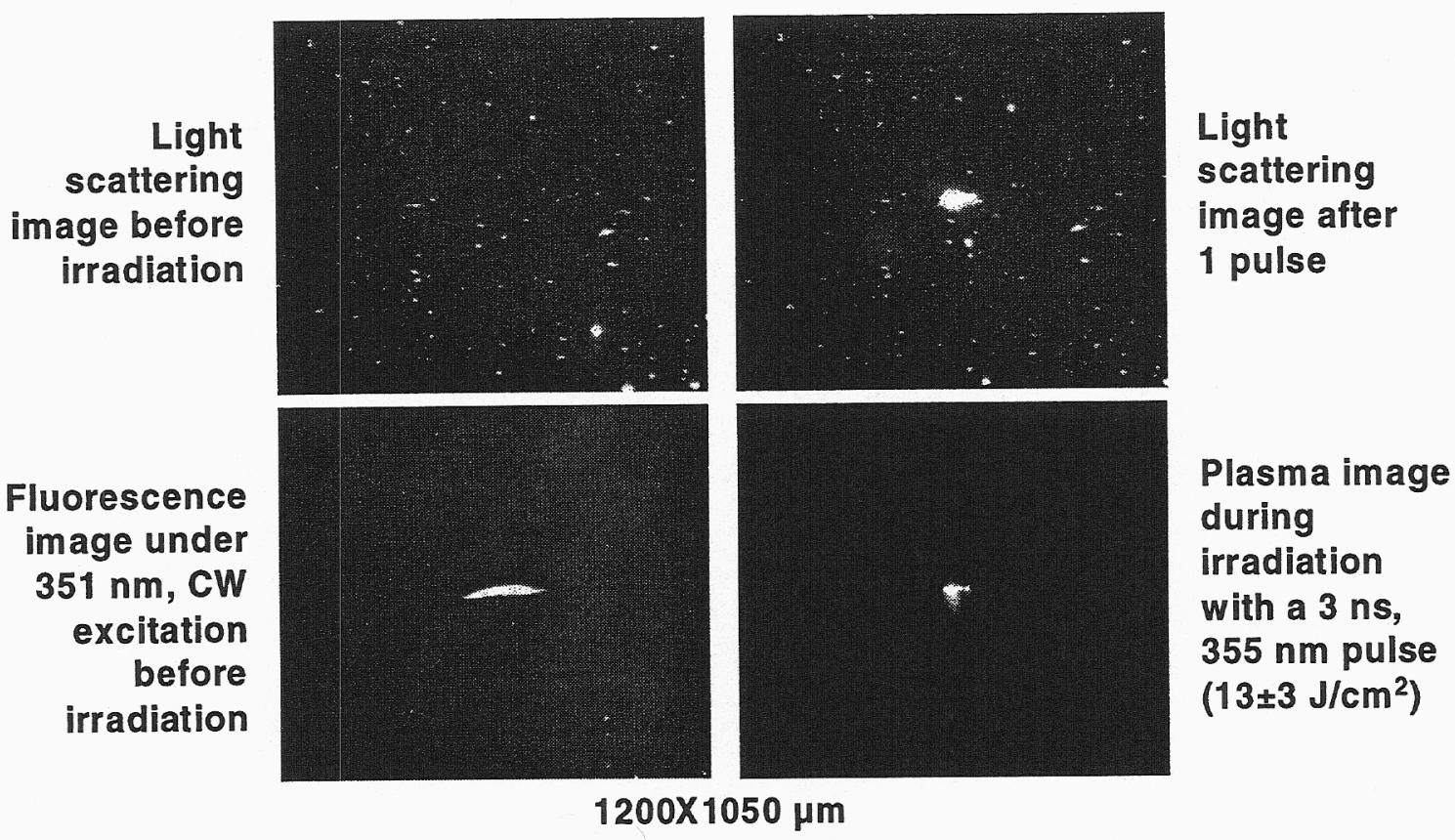

Figure 3. Light scattering and fluorescence images of high quality DKDP surface compared to images of the plasma image during high-fluence laser exposure and the light-scattering image thereafter. The large fluorescent body appears to be the precursor of the laser-induced damage.

Publications

M. Runkel and A. Burnham, "Differences in bulk damage probability distributions between tripler and z-cuts of KDP and DKDP at $355 \mathrm{~nm}$," LLNL Report UCRL-JC139622 (2000), Submitted to Proceedings of the 2000 Boulder Damage Symposium (2001).

A. K. Burnham, M.Runkel, R. Hawley-Fedder, L. Carman, R. Torres, P. Whitman, "Lowtemperature growth of DKDP for improved $3 \omega$-damage resistance," LLNL Report UCRL-JC139648 (2000), Submitted to Proceedings of the 2000 Boulder Damage Symposium (2001).

M. Runkel, A. Burnham, D. Milam, W. Sell, M. Feit, A. Rubenchik, "The results of pulsescaling experiments on rapid-growth DKDP triplers using the Optical Sciences Laser at 351 nm," LLNL Report UCRL-JC-139623 (2000), Submitted to Proceedings of the 2000 Boulder Damage Symposium (2001). 